\section{FUTURISTIT PUHTAAN SÄVELEN TYRANNIAA VASTAAN, UUSIEN AISTINAUTINTOJEN PUOLESTA!}

Meri Kytö

Luigi Russolo: Hälyjen taide

Helsinki: Tutkijaliitto, 2018

99 sivua

Suomentanut Tanja Tiekso.

Luin Hälyjen taiteen lentomatkalla Berliiniin. Lennon aikana kohtasimme turbulenssia, joka sai koneen ja siinä matkustavat nytkymään, tärisemään ja heittelehtimään vasemmalta oikealle. Lentopelon aiheuttamaa epämukavuutta lieventääkseni yritin ajatella kuin Luigi Russolo. Pyrin nuotintamaan hyytelömäistä hyllymistä rytmeiksi ja toistuvuuksiksi, estetisoimaan koneesta kuuluvaa rutinaa ja vingahtelua.

Hälyjen taide (alkuperäiseltä nimeltään L'arte dei rumori) on kokoelma italialaisen kuvataiteilija, soitinrakentaja ja konserttiarvostelija Luigi Russolon (1883-1947) tekstejä, jotka ovat ilmestyneet vuosien 1913-1916 välillä. Tunnetuin näistä teksteistä on kokoelman aloittava "Hälyjen taide - futuristinen manifesti", jossa Russolo ponnekkaasti esittelee näkemyksensä musiikin tulevaisuudesta. Manifestin lisäksi kirja sisältää tekstejä hälyviritinorkesterin alkuaikojen koettelemuksista, hälyvirittimien ominaisuuksista ja niiden akustisista periaatteista, kirjoituksia ympäristöäänten sointiväreistä ja rytmeistä, sodan äänistä, kielen hälyistä (eli konsonanteista) sekä enharmonian periaatteista.
Keskeisessä osassa tätä uutta modernin ajan äänellistä taidetta ovat Russolon suunnittelemat ja rakentamat hälysoittimet tai pikemminkin "hälyvirittimet" (intonarumori). Kyse on siis nimenomaan hälyn virittäjistä, eli instrumenteista joiden aiheuttaman äänen korkeutta pystytään portaattomasti säätelemään. Osa instrumenteista oli mekaanisia, osa toimi apunaan sähköakku. Muodoltaan ne olivat erikokoisia laatikoita, joissa oli kampi, torvi, vipu, viisari ja sisällä resonoivia kalvoja. Soittimet on taksonomisoitu perheisiin niistä kammettaessa syntyvien äänien yhtäläisyyksien perusteella. Kirjassa on esitelty ulistajat, jyristäjät, rätistäjät, hankaajat, pamauttajat, pulputtajat, päristäjät ja suhistajat. Kuten arvata saattaa, ovat suomennokset näille hyvin tervetulleita ja mielestäni onnistuneita. Russolo esittelee soittimiensa sointivärejä ja kuvaa niitä ihaillen mystisiksi, lumoaviksi, humoristisiksi, tunteikkaiksi, suloisiksi, kiehtoviksi ja sympaattisiksi.

Russolo ei ollut futuristinen meluriiviö: hän myöntää, että korva tarvitsee lepoa kaikesta äänestä - ei vain hälyistä vaan myös Beethovenista (s. 49). Hän ei suoranaisesti ollut fasismin puolesta, mutta ei aktiivisesti sitä vastaankaan: hän oli väkivaltaa kaihtamattoman kansallismielinen kuten monet aikalaisensa ennen Ensimmäisen maailmansodan koneistetun tappamisen verilöylyjä. On ajoittain kummaa yrittää seurata Russolon affektin läikyntää hänen kuvatessaan sodan ääniä täysin esteettisestä kuulokulmasta. Tämä herätti minussa ajatuksen äänen universalimin perimmäisestä tunteettomuudesta, jossa "itse ääni" on estetisoitu älyn leikiksi. Tämä tosin saattaa olla ylitulkintaa osaltani.

Russolon mukaan jokaisella hälyllä on (harmonisilta ominaisuuksiltaan rikas) äänenkorkeus. Äänen portaattomuus ja tasavireisyyden hylkiminen, eli enharmonia, on hänen mukaansa luonnonmukainen hälyjen ominaisuus. Hän näkee paljon vaivaa kart- 
taakseen sanaa glissando. Mielenkiintoista olisi myös tietää, mitä Russolo ajatteli aikalaisensa, Lev Termenin, liukuvasta sähkösoittimisesta, thereministä. Oliko siinä aineksia hälyvirittimien orkesteriin vai olisiko se ollut liian kliininen ja sointiväriltään köyhä joskin mestarillisesti enharmoninen vimpain?

Kääntäjä Tanja Tiekson kontekstoiva esipuhe kirjaan on tarpeellinen, jotta ajankuva ja tekstien ajoittain rempseys asettuu sopiviin kehyksiin. Tiekso on itse väitellyt 1900-luvun musiikin avantgardesta. Kuten hän esipuheessaan kirjoittaa, Russolon ajatukset, kirjoitukset ja toimet ovat vaikuttaneet merkittävästi 1900-luvun musiikkiin ja äänitaiteeseen, elektronisen ja akusmaattisen musiikin kehittämiseen, akustiseen ekologiaan, syväkuunteluun ja ympäristön äänien ja musiikin rajan hälvenemiseen ylipäätään. Ympäristön äänet ovat toimineet Russolon innoittajana, mutta niiden kuunteleminen ei futuristille riitä. Ympäristön äänet tulee hallita, alistaa ja täten pakottaa taiteen elementeiksi. Tekstikokoelma päätyy toiveeseen tulevaisuudesta, jossa hälyääniä on opittu kuulemaan abstrakteina ja autonomisina, eli akusmaattisina lähteidensä merkityssisällöistä irrotettuina. Tämä on Russolon tarjoama "uusi akustinen nautinto" (s. 99), jossa kiteytyy ajalleen tyypillinen, mutta nykyään ongelmallinen ajatus musiikista universaalina kielenä ja autonomiaestetiikan alaisena taidemuotona.

Russolon kieli on herkullisen räväkkää julistavuudessaan ja suomennos tekee sille oikeutta. On hykerryttävää kuulla kuvauksia orkesterin ensiesiintymisten vauhdista ja vaarallisista tilanteista, mitään tajuamattomista yleisön jäsenistä, imbesilleistä ja snobeista, järkyttyneistä porvareista ja poliisien puuttumista esityksiin: "yleisö ei kuullut mitään tuona iltana, yksinkertaisesti siksi, että he mieluummin tuottivat omia virittämättömiä hälyääniään!” (s. 36) Kyseistä konserttia Russolo-parka piti musiikillisesti onnistu-

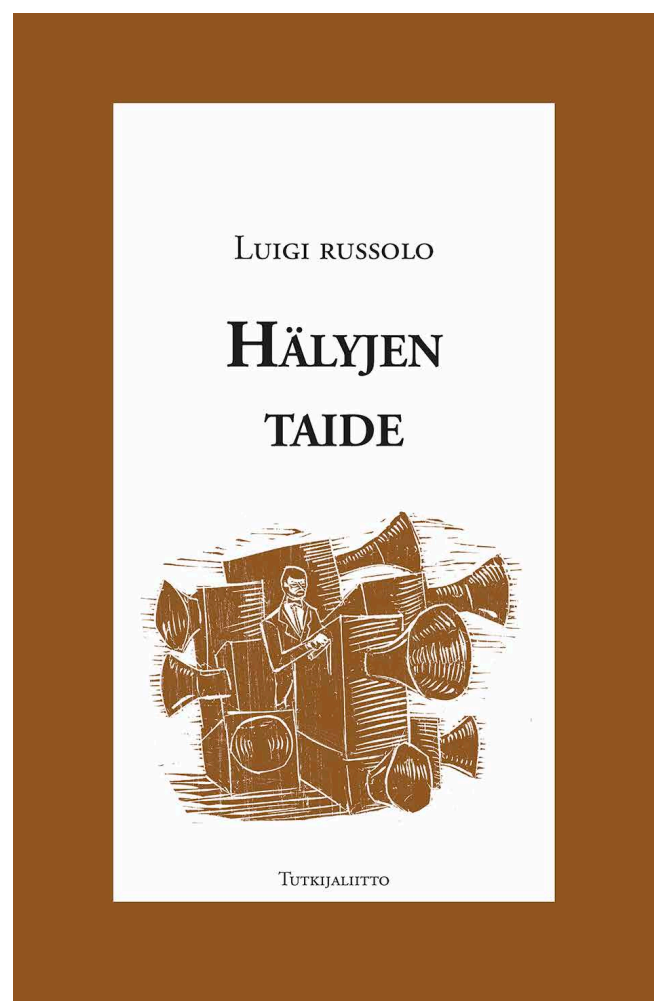

neimpana hälyorkesterinsa esityksenä, vaikka pariisilainen kriitikko olikin kirjoittanut kyseisestä esityksestä seuraavasti: "Verisiä kasvoja, hälyjen enharmoniaa, helvetillinen mekkala. Hernanin taistelut eivät olleet mitään verrattuna tähän rähinään” (s. 37). Sinnikkyyden puutteesta Russoloa ei tosiaan voi syyttää. Hän toteaa, että orkesterin suosion esteenä on lähinnä "yleisön ääliömäisyys, siis jos heitä ei huvita kuunnella... Mutta toivomme ja uskomme vakaasti, että voitamme jopa senkin" (s. 95).

Ympäristöäänien sointivärejä kuvaileva luku on äänimaisematutkimuksen kuulokulmasta tavattoman kiinnostava. Russolo kertoo haluavansa johdattaa lukijan "ymmärtämään ja ihailemaan hälyjä, joita luonto ja elämä tarjoavat" (s. 46) ja kirjoittaa: "sille, joka hälyä tuntee ja ymmärtää, edustaa se ehtymätöntä aistimusten lähdettä. Aina hienostunutta ja syvää, suurenmoista ja yle- 
vää” (s. 46). Hän kuvaa skotlantilaisen Fingalin luolan lumoavaa akustiikkaa ja lasten kykyä imitoida ääniä. Kaupungin hulinaa ja sen hiljaista basso continuota ikkunastaan kuunnellen hän muistuttaa Henri Lefebvreä rytmianalyyseineen. Tässä tekstissä Russolo myös toteaa, että hälysoittimien kanssa pelaaminen muuttaa myös asennoitumista arjen hälyääniin esteettisemmäksi ja täten tyydyttävämmäksi. Tämä huomio vertautuu äänimaisemapedagogi R. M. Schaferin kirjoituksiin 1970-luvulla.

Russolo paljastaa aikakautensa musiikkikulttuurin antamalla nuotinnoksen haasteelle tilaa kirjoituksissaan. Säveltäjän työ oli tehdä nuotteja muusikoille esitettäväksi. Nykyajan koneorkesterien sointivärivastaavat eli tuottajat eivät nuotinna, koska koneiden kanssa työskennellessä sitä ei tarvitse tehdä. Lisäksi on huomionarvoista, että Russololle orkesteri eli kokoelma soittimia itsessään oli teoksenomainen olio: tavoitteena hänellä oli luoda hälyorkesterista "täydellinen itsessään, sellaisena kuin se on" (s. 93). Tämä saattaa johtua hänen taustastaan kuvataiteilijana.

Ääniä kuvaavat sanat ovat usein hankalia käännettäviä, koska ne ovat harvoin eksplisiittisiä kuvaamastaan kohteesta. Esimerkkinä tästä sivulla 29 Russolo luettelee futuristisen orkesterin hälyperheet. Näistä ensimmäinen sisältää alkuperäiskielellä seuraavat äänet:

rombi, tuoni, scoppi, scrosci, tonfi, boati, jotka Tiekso on kääntänyt:

jylinät, jyrinät, paukahdukset, kohinat, tömähdykset, kuminat

Englanninnokset samasta hälyperheestä tarjoaa Barkley Brown (1986):

roars, thunderings, explosions, hissing roars, bangs, booms

Ranskankielisessä pamfletissa vuodelta 1913 (http://luigi.russolo.free.fr/mani1. html) kyseisessä hälyperheessä on kuuden äänen sijasta viisi ääntä: grondements, éclat, bruit d'eau tombante, bruits de plongeon, mugissements, jotka Robert Filliou (1967) on kääntänyt englanniksi:

roars, claps, noises of falling water, driving noises, bellows

Ei ole mitenkään yksiselitteistä kuvitella mielessään, mitä ääniä näillä sanoilla on pyritty kuvaamaan (scrosci - hissing roar - noise of falling water - kohina). Sitä vaikeampaa on pyrkiä kääntämään kuvaileva sana toiselle kielelle menettämättä niiden yksityiskohtaisuuksia ja kulttuurista käyttöyhteyttä, jos tämä ylipäätään on mahdollista.

Osa Russolon toiveista tulevaisuuden musiikiksi on toteutunut: "Futurististen muusikkojen tulee korvata nykyorkesterin soittimien tarjoama rajallinen sointivärien valikoima loppumattomalla joukolla hälyjen sointivärejä, joita erityisillä koneilla tuotetaan" (s. 30). Mielenkiintoinen ja ajankohtainen on myös ajatus hälyn suunnittelusta, eräänlaisesta äänimaisemadesignista: "Niinpä jonain päivänä voivat teollisten suurkaupunkiemme moottorit ja koneet olla niin taitavasti viritettyjä, että jokaisesta tehtaasta voi tulla juovuttava hälyjen orkesteri” (s. 31). Viime vuosikymmenien kehitys, joissa raskaan teollisuuden muuttaminen keskustoista taajamiin on hiljentänyt kaupunkeja ja digitalisaation hiljainen tuulettimien humina on vallannut jäljelle jääneen tilan, on muuntanut kaupunkien atmosfääriä pois polttomoottorien ja raskaiden koneiden käyntiäänistä. Tilalle tuli muzak ja ostoskeskuksien sensoripohjaiset taustaäänigeneraattorit. Ehkä lähempänä Russolon koneromanttista mielikuvitusta on kohtaus Lars von Trierin elokuvasta Dancer in the dark (2000), jossa Björkin esittämä päähenkilö laulaa ja tanssii rytmikkään tehdaspopin säestämänä. Tämä tosin olisi ollut Russololle luultavasti liian matalamielistä ja epä-enharmonista. Iloisena yllätyksenä hänelle olisi toisaalta tullut 
orkesterisoittimien soittotapojen hälyrikas lisääntyminen hälyrikkaampaan suuntaan pois puhtaan sävelen tyranniasta - ja soittokokoonpanojen moninaisuus, sähköllä ja ilman. Vaikka hänen rakentamiaan hälyvirittimiä ei olekaan käytössä, äänimaailmat jotka niistä (luultavasti) lähtivät ovat tulleet osaksi musiikin arkipäivää.

Käännös on hyvin sujuvaa luettavaa ja tuo Russolon värikkään ilmaisun hyvin esille. Kohta, jossa olisin itse suomentanut toisin, on sivulla 92: olisin vaihtanut "timpaanin" patarummuksi ja "sistron" sistrumiksi, mutta nämä ovat kosmetiikkaa. Tiekso ja Tutkijaliitto ovat tehneet merkittävän kulttuurityön tarjotessaan tämän teoksen vihdoin suomeksi kaikille musiikista, äänestä ja taiteesta kiinnostuneille lukijoille.

Dosentti Meri Kytö työskentelee Tampereen yliopiston Informaatioteknologian ja viestinnän tiedekunnassa erityisalanaan kulttuurinen äänentutkimus ja äänimaisematutkimus. 